\title{
IMPLEMENTASI PERMAINAN TRADISIONAL BERBASIS BUDAYA LOKAL PADA MATERI POKOK KOLOID UNTUK MENINGKATKAN KEMANDIRIAN BELAJAR SISWA KELAS XI SMA NEGERI 10 BANJARMASIN
}

\section{Implementation of Traditional Game Based on Local Culture on Colloid Topic to Enhance Students' Learning Independence at Class XI SMA Negeri 10 Banjarmasin}

Ayu Dita Subroto, Mohan Taufiq Mashuri, Okviyoandra Akhyar Program Studi Pendidikan Kimia Fakultas Keguruan dan Ilmu Pendidikan Universitas Islam Kalimantan (Uniska) Muhammad Arsyad Al Banjari, Banjarmasin *email: ayuditasubroto@yahoo.co.id

\begin{abstract}
Abstrak.Penelitian ini dilakukan di SMA Negeri 10 Banjarmasin. Tujuan penelitian ini adalah untuk (1) Mengetahui kemandirian belajar siswa sebelum dilakukan eksperimen (2) Mengetahui hasil dari implementasi permainan tradisional berbasis budaya lokal apakah dapat meningkatkan kemandirian belajar siswa.Penelitian ini merupakan penelitian kuantitatif yang bersifat penelitian semu (Quasy Eksperiment). Populasi dalam penelitian ini adalah siswa kelas XI SMA Negeri 10 Banjarmasin. Sampel pada penelitian ini dua kelas yang diambil yakni kelas kontrol (XI IPA 1) sebanyak 33 orang siswa dan kelas eksperimen (XI IPA 2) sebanyak 34 orang siswa. Teknik pengumpulan data menggunakan observasi dan angket. Dari hasil analisis data melalui perhitungan manual dengan uji-t diperoleh nilai thitung lebih besar dari pada tabel (thitung 4,710 > tabel 2,000). Hal ini menunjukkan bahwa terdapat peningkatan kemandirian belajar kimia siswa kelas XI SMA Negeri 10 Banjarmasin pada materi pokok koloid.
\end{abstract}

Kata Kunci: Permainan Tradisional, Budaya Lokal, Kemandirian Belajar

\begin{abstract}
This research was conducted in SMA Negeri 10 Banjarmasin. The purposes of this study are: (1) To know the independence of student learning before the experiment (2) To find out the results of the implementation of traditional games based on local culture if it can improve students' learning independence. The type of this research was quantitative research called Quasy Eksperiment. Population in this research were all students of class XI in Senior High School 10 Banjarmasin. The sample in this study used two classes that were taken by random techniques, the control class was XI Science 1 consists of 33 students and experimental class (XI Science 2) were 34 students. The data collection techniques used observation and questionnaires. From the results of data analysis through manual calculations with $t$-test obtained the value of $t_{\text {count }}$ is greater than $t_{\text {table }}\left(t_{\text {count }} 4.710>t_{\text {table }}\right.$ 2,000). This indicates that there is an increase in the independence of chemistry learning by students of class XI SMA Negeri 10 Banjarmasin on colloid topic.
\end{abstract}

Keywords: Traditional Games, Local Culture, Learning Independence 


\section{PENDAHULUAN}

Pada hakekatnya, pendidikan merupakan salah satu kegiatan yang mencakup kegiatan mendidik, mengajar dan melatih. Dalam serangkaian proses pembelajaran di sekolah, kegiatan belajar mengajar merupakan kegiatan yang paling penting. Menurut Wena (2009), pembelajaran yang selama ini ada kurang inovatif, pembelajaran banyak berpusat kepada guru sehingga kurang mengembangkan potensi yang ada di dalam diri siswa. Seringkali guru juga belum optimal dalam melibatkan siswa secara aktif pada kegiatan pembelajaran, serta lebih sering menyuruh siswa mendengarkan penjelasan guru. Menurut Silberman (2006), guru berbicara dengan kecepatan 100 hingga 200 kata per menit, tetapi jika siswa benarbenar berkonsentrasi, mereka akan dapat mendengarkan dengan penuh perhatian terhadap 50 hingga 100 kata per menit. Artinya, siswa hanya dapat mendengarkan setengah dari apa yang guru bicarakan.

Menurut Tirtarahardja \& Sulo (2005), permasalahan-permasalahan pembelajaran yang terjadi di dalam dunia pendidikan tersebut salah satunya dipengaruhi oleh kurikulum, terutama Kurikulum Tingkat Satuan Pendidikan (KTSP) yang pada proses penerapannya berpusat pada guru (teacher centered) dan ini merupakan kurikulum yang digunakan di SMA Negeri 10 Banjarmasin. Berlakunya KTSP menuntut guru agar mampu menyusun suatu pembelajaran yang menumbuhkan kemandirian belajar siswa.

Dari hasil pengamatan dan wawancara singkat peneliti kepada guru mata pelajaran kimia kelas XI di SMA Negeri 10 Banjarmasin, kasus-kasus aktual yang juga ditemukan ialah seperti siswa yang menyontek di kala sedang menghadapi tes/ ujian, bersikap malas pada saat diberikan tugas/pekerjaan rumah oleh guru, tinggal menunggu hasil pekerjaan dari temannya, tidak berani bertanya atau mengemukakan pendapat, dan lain-lain. Hal ini merupakan salah satu karakter yang ditunjukkan oleh siswa yang tidak mandiri.Oleh karena itu kemandirian belajar sangatlah penting dimiliki oleh setiap siswa agar sifat-sifat malas, suka menyontek dan tidak mengerjakan tugas yang diberikan oleh guru dapat diminimalisir.

Upaya peningkatan kemandirian belajar diharapkan dapat memupuk rasa tanggung jawab, meningkatkan keterampilan, dapat memecahkan setiap masalah, inisiatif, dapat berpikir kreatif, berpikir kritis dan memiliki rasa percaya diri yang kuat.

Menurut Steinberg (2002), kemandirian didefinisikan sebagai kemampuan individu dalam bertingkah laku, merasakan sesuatu, dan mengambil keputusan berdasar kehendaknya sendiri.Peningkatan tanggung jawab, kemandirian, dan menurunnya tingkat ketergantungan remaja terhadap orang tua, adalah perkembangan yang harus dipenuhi individu pada periode remaja.Adanya berbagai permasalahan tersebut memancing keinginan peneliti untuk meningkatkan kemandirian belajar siswa khususnya pada mata pelajaran Kimia di kelas XI. Seperti yang dinyatakan Sumarmo(2010) bahwa individu yang memiliki kemandirian belajar yang tinggi cenderung belajar lebih aktif, mampu memantau, mengevaluasi, dan mengatur belajar lebih efektif yaitu menghemat waktu dalam menyelesaikan tugasnya, mengatur waktu belajar secara efisien dan memperoleh skor tertinggi dalam sains. Jadi, kemandirian belajar merupakan salah satu aspek afektif yang perlu ditingkatkan untuk mendukung keberhasilan belajar siswa.

Menyadari pentingnya meningkatkan kemandirian belajar siswa, maka diperlukan suatu strategi dan pendekatan pembelajaran yang lebih banyak melibatkan siswa secara aktif dalam proses pembelajaran. Salah satu upaya yang 
ingin dilakukan untuk meningkatkan kemandirian belajar siswa di sini adalah dengan penerapan strategi pembelajaran yang bersifat menyenangkan seperti strategi pembelajaran menggunakan permainan tradisional berbasis budaya lokal. Permainan tradisional merupakan permainan yang relatif sederhana namun memberikan manfaat luar biasa jika kita menelusuri makna dari permainan itu secara mendalam, namun keberadaannya sekarang mulai tergeser oleh permainan modern.

Permainan tradisonal yang ingin diimplementasikan di sini ialah permainan tradisonal "Ular Naga" khas kebudayaan Banjar. Permainan ini biasanya dilakukan di lapangan terbuka yang mana nantinya juga akan dikondisikan pada saat penerapannya yaitu di luar kelas. Dengan strategi pembelajaran menggunakan permainan tradisional ini, diharapkan peserta didik dapat menjadi lebih aktif sehingga terciptalah proses pembelajaran yang lebih hidup dan menyenangkan, serta tujuan utama untuk meningkatkan kemandirian siswa dalam belajar dapat tercapai.

Banyak sekali manfaat yang di dapatkan dari permainan ular naga ini. Menurut Indah (2015) berikut adalah beberapa manfaat positif yang dapat kita ambil khususnya bagi anak-anak yaitu seperti semakin mempererat ikatan kita dengan teman, belajar menjadi pemimpin yang baik, melatih emosional dan kecakapannya dalam berkomunikasi.Selain itu permainan ini juga mendidik anak tentang arti kebersamaan dan menghargai orang lain, serta membuat fisik menjadi sehat karena menggerakan anggota badan.

Adapun manfaat yang diharapkan peneliti pada pengimplementasian permainan ular naga di kelas XI SMA Negeri 10 Banjarmasin nantinya ialah sebagai berikut : 1) Siswa merasa ceria dan senang dalam belajar kimia di sekolah; 2) Permainan ular naga dapat membuat siswa lebih aktif dan mandiri dalam proses pembelajaran; 3) Baik Siswa maupun guru menjadi lebih tau dan lebih memperhatikan lagi bahwa permainan tradisional terutama permainan ular naga yang berbasis budaya lokal khas Banjar perlu terus dilestarikan agar keberadaannya tidak hilang tergerus zaman.

Berdasarkan latar belakang di atas maka dilakukan penelitian dengan judul "Implementasi Permainan Tradisional Berbasis Budaya Lokal Pada Materi Pokok Koloid untuk Meningkatkan Kemandirian Belajar Siswa Kelas XI SMA Negeri 10 Banjarmasin"

\section{METODE PENELITIAN}

Jenis penelitian ini adalah eksperimen semu (Quasy Eksperiment) dengan desain penelitian yang berbentuk pretest-posttest control group design. Penelitian dilaksanakan di SMA Negeri 10 Banjarmasin mulai bulan April sampai Mei 2017. Populasi dari penelitian ini adalah seluruh kelas XI IPA sedangkan sampel penelitian yaitu kelas XI IPA 2 sebagai kelas eksperimen dan kelas XI IPA 1 sebagai kelas kontrol. Instrumen yang digunakan dalam penelitian ini yaitu rencana pelaksanaan pembelajaran (RPP),lembar observasi, dan angket.Sebelum instrumen-instrumen tersebut dapat digunakan dalam penelitian maka perlu diuji kelayakannya. Untuk RPP, dan lembar observasi dengan meminta judgement pada dosen, guru mata pelajaran kimia di sekolah atau orang yang dianggap ahli sedangkan untuk angket menggunakan rumus perhitungan uji validitas dan uji reliabilitas. Validasi dilakukan di kelas XII IPA 1.Uji validitas dihitung menggunakan rumus korelasiProduct Moment(Arikunto, 2006)sedangkan uji reliabilitas menggunakan rumus Cronbach Alpha(Sugiyono, 2009).Kemudian setelah data penelitian diperoleh, data perlu melalui uji persyaratan yaitu uji normalitas dan uji homogenitas.Uji normalitas menggunakan rumus Liliefors sedangkan uji homogenitas untuk dua kelompok data 
menggunakanrumus uji F (Sugiyono, 2013).Setelah melalui uji persyaratan, maka diuji hipotesis.kemudian uji N-Gain untuk melihat peningkatan kemandirian belajar siswa.

\section{HASIL PENELITIAN DAN PEMBAHASAN}

Hasil analisis uji validitas angket menggunakan rumus korelasi product moment dari 35 butir pernyataan diperoleh 23 butir pernyataan valid, dengan kata lain angket dapat mengukur kemandirian belajar siswa. kemudian diuji reliabilitasnya menggunakan rumus cronbach alpha, hasil uji sebesar 0.97 tergolong memiliki tingkat keterandalan instrumen sangat tinggi, dengan kata lain angket dapat dipercaya untuk digunakan sebagai alat pengumpul data. Angket ini dibagikan pada siswa sebelum diberi perlakuan (pretest) dan sesudah diberi perlakuan (posttest) dimana kelas eksperimen menggunakan strategi pembelajaran permainan tradisional "Ular Naga" khas kebudayaan Banjar sedangkan kelas kontrol tanpa menggunakan strategi pembelajaran ular naga.

Setelah didapatkan data pretest dan posttest maka data diuji normalitas dan homogenitasnya. Berdasarkan analisa data yang telah dilakukan, diperoleh hasil bahwa data berdistribusi normal dan homogen.Selanjutnya dilakukan uji-t untuk menguji hipotesis.Hasil uji-t yang dilakukan terhadap kemandirian belajar siswa

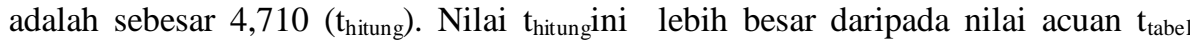
2,000. Berdasarkan kaidah pengambilan keputusan, dari hasil penelitian tersebut dapat disimpulkan bahwa jika $t_{\text {hitung }}>t_{\text {tabel }}$ maka $\mathrm{H}_{\mathrm{a}}$ diterima dan $\mathrm{H}_{\mathrm{o}}$ ditolak, sehingga hipotesis penelitian $\left(\mathrm{H}_{\mathrm{a}}\right)$ diterima, yaitu ada peningkatankemandirian belajar siswa setelah diberi perlakuan dengan menggunakan strategi permainan tradisional "Ular Naga" khas kebudayaan Banjar.

\section{SIMPULAN}

Berdasarkan hasil dan analisa peneliti diperoleh kesimpulan bahwa penerapan permainan tradisional berbasis budaya lokaldapat meningkatkankemandirian belajar kimia siswa kelas XI IPA 2 SMA Negeri 10 Banjarmasin pada materi Koloid, dilihat dari hasil uji hipotesis yang menyatakan bahwa terdapat perbedaan yang signifikan pada kemandirian belajar sebelum dan sesudah diberi perlakuan dengan kemandirian belajar kelas eksperimen yang lebih tinggi dari kelas kontrol. Saran dari peneliti antara lain permainan tradisional berbasis budaya lokal khususnya permainan "Ular Naga" khas kebudayaan Banjar dapat menjadi bahan pertimbangan oleh guru-guru kimia sebagai variasi dalam melaksanakan pembelajaran untuk menarik kemandirian belajar siswa, dalam menerapkan permaianan tradisional "Ular Naga" peneliti atau pengajar harus mengupayakan sistem kontrol yang lebih baik agar proses penerapannya dapat berjalan dengan optimal dan efisien baik dari segi management waktu, tempat pelaksanaan, hingga materi pelajaran yang akan digunakan.

\section{DAFTAR RUJUKAN}

Arikunto, S. (2006). Prosedur Penelitian Suatu Pendekatan Praktik. Jakarta: PT Rineka Cipta.

Arikunto, S. (2013). Dasar-dasar Evaluasi Pendidikan Edisi 2. Jakarta: Bumi Aksara.

Febriastuti, Y. D. (2013). Peningkatan Kemandirian Belajar Siswa SMP Negeri 2 Geyer Melalui Pembelajaran Inkuiri Berbasis Proyek. Semarang: UNNES.

Indah, P. H. (2015). Permainan Tradisional Ular Naga. Bandung: Universitas Pendidikan Indonesia. 
Dalton : Jurnal Pendidikan Kimia dan Ilmu Kimia, Volume 1 Nomor 1, Mei 2018

Qudsiyah, F. H. (2013). Implementasi Praktikum Aplikatif Berorientasi Chemoentrepreneurship (CEP) Terhadap Peningkatan Hasil Belajar Kimia Materi Pokok Koloid Siswa Kelas XI. Semarang: UNNES.

Silberman, M. L. (2006). Active Learning: 101 Cara Belajar Siswa Aktif (3rd ed.). Bandung: PT Nusamedia.

Steinberg, L. (2002). adolescene (6th ed.). New York: McGraw-Hill.

Sugiyono. (2009). Statistik Untuk Penelitian. Bandung: PT Alfabeta.

Sugiyono. (2013). Metodologi Penelitian Kuantitatif, Kualitatif, dan $R \& D$. Bandung: PT Alfabeta.

Sugiyono. (2016). Metode Penelitian Pendidikan. Bandung: Alfabeta.

Sumarmo, U. (2010). Berpikir dan Disposisi Matematik:Apa, Mengapa, dan Bagaimana Dikembangkan pada Peserta Didik. Bandung: Universitas Pendidikan Indonesia.

Tirtarahardja, U., \& Sulo, L. (2005). Pengantar Pendidikan. Jakarta: PT Rineka Cipta.

Wena, M. (2009). Strategi Pembelajaran Inovatif Kontemporer. Jakarta: Bumi Aksara. 